\title{
Steady-state DCM dynamics in Canaries waters
}

Paul Tett ${ }^{\mathrm{a}} *$, Javier Arístegui ${ }^{\mathrm{b}}$, Des Barton ${ }^{\mathrm{c}}$, Gotzon Basterretxea ${ }^{\mathrm{b}, 1}$, J.D. De Armas ${ }^{\mathrm{d}}$, José E. Escánez , Santiago Hernández León , Luisa M Lorenzo , Nandi Montero ${ }^{\mathrm{b}}$

${ }^{\text {a }}$ School of Life Sciences, Napier University, Edinburgh EH10 5DT, UK

${ }^{\mathrm{b}}$ Department of Biology, Universidad de Las Palmas de Gran Canaria, Campus Universitario de Tafira, 35017 Las Palmas de G.C., Spain

${ }^{c}$ School of Ocean Sciences, University of Wales, Bangor LL59 5EY, UK

${ }^{d}$ Instituto Español de Oceanografía, 38180 Santa Cruz de Tenerife, Spain

${ }^{\mathrm{e}}$ Instituto de Investigaciones Marinas, 36208 Vigo, Spain

*Corresponding author.

E-mail address: p.tett@ichrachan.u-net.com (P. Tett).

Now at IMEDEA, Miquel Marques 21, 07190 Esporles, Baleares, España

\section{Abstract}

This paper concerns the deep chlorophyll maximum (DCM) dynamics in a steady state, using primarily data from the Canary Islands Area of Filament and Eddy eXchange obtained in August 1999 during a cruise between oligotrophic waters west of La Palma and the north-west African coastal upwelling. CTD-fluorometer observations of the deep fluorescence maximum (DFM) were confirmed by water samples from which chlorophyll was extracted. The DFM- DCM was perturbed at many stations by island-generated eddies and similar features, and the paper focuses on unperturbed stations, which were identified by the occurrence of the DFM close to the $26.4 \mathrm{~kg}$ $\mathrm{m}^{-3}$ isopycnal. The DFM at these stations occurred at the top of the nitracline, in the presence of $0.3-2 \mu \mathrm{M}$ nitrate+nitrite, and at $24 \mathrm{~h}$ mean isolumes of $10-20 \mu \mathrm{Em}^{-2} \mathrm{~s}{ }^{-1}$. The classical compensation depth model predicts the occurrence of the DFM-DCM at less illumination and hence at too great a depth, making it necessary to take into account additional losses, especially those due to the respiration of microheterotrophs in biomass equilibrium with phytoplankton. 
The depth of the steady-state DCM is compatible with the predictions of a microplankton model, given (i) a ratio of $0.3-0.6$ of microheterotroph to total microplankton biomass, and (ii) other losses (due to meszooplankton grazing and vertical mixing) of about $0.1 \mathrm{~d}^{-1}$.

\section{Introduction}

The deep chlorophyll maximum (DCM) is a widespread feature of the oceans and lakes (Lindholm, 1992), and is a near-permanent feature of the oligotrophic waters of the subtropical parts of the ocean gyres (Cullen, 1982). The North Atlantic gyre is no exception, and persistent DCMs or deep fluorescence maxima (DFMs) have been reported, for example, by Fasham et al. (1985) and Agusti and Duarte (1999). The Canary Islands Area of Filament and Eddy eXchange (AFEX) lies in the south-eastern part of this gyre, and provides an environment (Barton et al., 1998) in which the DCM can be studied over the range of steady state and perturbed conditions associated with upwelling and island mixing. This paper concerns the dynamics of the DCM in a steady state, as observed in Canaries waters during cruises by B.I.O. Hesperides in August 1993 (Barton et al., 1998; Basterretxea and Arístegui, 2000) and August 1999. Our analysis is aimed at (a) better understanding of an important global feature using a modification of the classical compensation depth model, and (b) explaining some features of the distribution of chlorophyll in the Canary Islands AFEX.

The classical concept of the compensation depth originated with Marshall and Orr (1928), who suspended diatom cultures in the sea for $24 \mathrm{~h}$ and used the light and dark bottle oxygen method to find the depth at which algal respiration exactly balanced photosynthesis. Phytoplankters cannot sustain growth below this depth. They also need nutrients, and so it may be expected that microalgal or cyanobacterial populations in nutrient-depleted, well-stratified waters will grow best when close to the compensation depth (Fig. 1(a)), because they thus gain first access to nutrient fluxes from mineralisation deeper in the ocean. Growth may be augmented by vertical migration towards the optimum level (Cullen and Eppley, 1981; Tett, 1987) and aided by lowlight adaptation. In the steady state, which is the concern of this paper, a growth optimum will be a biomass maximum, unless grazers focus on the optimum region. 
In this paper we use the depth at which the maximum of photosynthetic pigment fluorescence occurs as a proxy for chlorophyll $\alpha$ and for phytoplankton biomass. It is hypothesised that this DFM occurs close to the depth of the compensation irradiance estimated in one of two ways. The first involves what we call the "classical" model, in which only the respiration of phytoplankters is taken into account. (Fig. 1(b)). The second method takes into account additional losses (Fig. 1(c)). As Smetacek and Passow (1990) emphasise, Sverdrup (1953) explicitly considered that the compensation depth "must lie higher for a mixed population of phyto-and zooplankton than for a pure phytoplankton" because of additional losses. Probably, Sverdrup had in mind the pelagic crustacea as the dominant zooplankters causing these losses. Here, however, we consider especially losses of primary production due to the respiration of heterotrophic microorganisms that make up the pelagic microbial loop (Williams, 1981; Azam et al., 1983) and which are a particularly important part of the plankton of the oligtrophic oceans (Legendre and Rassoulzadegan, 1995). Tett et al. (1988) added microheterotroph losses to phytoplankton respiration to estimate a microplankton community compensation depth that lies closer to the sea surface than the algal compensation depth. Tett (1990a) suggested that, although the original work on the compensation depth by Marshall and Orr (1928) dealt with a true balance between algal photosynthesis and respiration, the value used for the compensation irradiance by Sverdrup (1953) probably, but unknowingly, took account of microheterotroph respiration.

Our calculations of the microbial loop compensation irradiance uses the algorithms of the microplankton model MP, originally proposed by Tett (1990b; see also Tett and Walne, 1995) and refined by Tett (1998; see also Smith and Tett, 2000; Tett and Wilson, 2000). MP describes the activities of the microbial loop as a single compartment, in which there is a balance between autotrophs and heterotrophs expressed by the value of $y$, the heterotroph fraction of total microplankton biomass. Within this compartment, nitrogen is efficiently recycled, but heterotroph respiration adds to losses of photosynthetically fixed carbon.

The MP parameterisation avoids the need to specify the grazing rates of pelagic ciliates or heterotrophic flagellates, or the DOM assimilation rates of bacteria. The microplankton 
compartment includes pelagic microorganisms belonging to the subkingdom Eubacteria (including cyanobacteria and heterotrophic bacteria) and the kingdom Protoctista (including microalgae and protozoa): these names are taken from Whittaker's 5-kingdom scheme (Margulis, 1993). Finally, the word "mesozooplankton" is used to mean the pelagic members of the kingdom Animalia that feed on microplankters, and which are characterised by longer timescales for population growth.

Our second aim in this paper is to explain some of the features of the distribution of chlorophyll in the Canaries AFEX that have been observed during a series of cruises that started in 1990 (Aristegui et al., 1997; Barton et al., 1998). Cruises on Hesperides in August 1993 and August 1999 commenced by working a standard transect, starting to the north-west of La Palma and ending close to the African coast (Fig. 2). This transect was called the Long Section, and was designed to record the general features of the AFEX. Each cruise then went on to study the detail of features, such as upwelled filaments and island-generated eddies, using finer station grids. The present paper focuses on results from the Long Section in 1999, but makes some use of data from other stations, and from the 1993 Hesperides cruise. Methods for the 1993 studies are given by Barton et al. (1998) and Basterretxea and Ar!ıstegui (2000). Irradiance data are reported in microEinsteins $(\mu \mathrm{E})$, corresponding to $10^{-6}$ mol of photons.

\section{Observational methods in 1999}

Standard stations were worked with a General Oceanics Mark III CTD equipped with a Sea-Tech linear-response fluorometer and a rosette of water bottles. Water-sample depths were chosen by inspection of density and fluorescence profiles. Chlorophyll in water-bottle samples was measured by GF/F filtration, extraction into $90 \%$ acetone, and determination of fluorescence before and after acidification with a Turner Designs bench fluorometer (Holm-Hansen et al., 1965) calibrated with pure chlorophyll a (Sigma Chemical Corp.). Water-sampled nutrients were determined by Continuous Flow Analysis using a Technicon-Bran Luebbe AA II AutoAnalyzer. In addition to nitrite and nitrate (Tréguer and Le Corre, 1975), nanomolar levels of nitrate+nitrite were determined in the upper layer $(0-100 \mathrm{~m})$ by the method of Oudot and Montel (1988). The 
total concentration of dissolved nitrate plus nitrite is referred to here as "total oxidised nitrogen" $\left(\mathrm{TO}_{\mathrm{x}} \mathrm{N}\right)$.

Photosynthetic parameters were measured by $\mathrm{NaH}^{14} \mathrm{CO}_{3}$ uptake during incubations of $3 \mathrm{~h}$ under illumination by tungsten halogen lamps. A light gradient was provided by frontal illumination of a row of bottles, and temperature was maintained at that of the sea at the depth of sampling. Fixed ${ }^{14} \mathrm{C}$ was determined by standard methods using scintillation. PAR in the incubator was measured with a LiCor cosine sensor LI-190SA. Maximum photosynthetic efficiency $\alpha_{\mathrm{m}}$ was estimated by fitting the model of Webb et al. (1974) to the photosynthesis-irradiance data.

Submarine photosynthetically active radiation (PAR) was calculated from measurements made with two instruments. At bio-optical stations, a LiCor 1800 submersible spectroradiometer with a cosine collector was used to make spectra of downwards quantum irradiance between 400 and $700 \mathrm{~nm}$ at a series of depths. The spectral irradiance was summed to give PAR. Depth was recorded as metres of wire out, with correction for wire angle, checked against an externally mounted self-recording pressure sensor. The depth and PAR data were mainly used to estimate diffuse attenuation coefficients, as further described below. A Kipp and Zonen pyrrheliometer mounted high on the ship's superstructure was used to provide a continuous measurement of total solar radiation at the sea surface. It was assumed that 0.46 of this radiation was PAR, and pyrrheliometer PAR Joules were converted to photons in air at $4.6 \mu \mathrm{EJ}^{-1}$ and to submarine photons at $4.15 \mu \mathrm{EJ}^{-1}$.

\section{Observations of density, fluorescence, chlorophyll and nitrate}

Observations during the Long Section in August 1999 (Fig. 3(b)) show a maximum of fluorescence at a depth of about $100 \mathrm{~m}$ in the oligotrophic far field, north-west of the island of La Palma. The maximum occurs at increasingly shallow depths as the upwelling zone of the African coast is approached. The diagram also shows upwards and downwards displacements of the deep fluorescence maximum (DFM) associated with: a small cold-core (upwelling) eddy at stations 2- 
3, near La Palma; an eddy pair at stations 7-9 (cold-core) and 10-11 (warm-core, downwelling) south-west of Tenerife; and features associated with Gran Canaria at stations 12-14. Perturbations at stations 20-22 were associated with a filament of upwelled water extending westwards from the African coast. A section along the same line in August 1993 (although with fewer stations) (Fig. 3(c); see also Fig. 17 of Barton et al., 1998) showed broadly similar features, although the effects of the islands were different in detail.

The DFM in August 1999 tended to be associated with $26.4 \mathrm{~kg} \mathrm{~m}^{-3}$, with large departures from this isopycnal only in the Tenerife eddy pair, in the filament crossing of stations $16-17$, and in the upwelling zone of stations 22-25 (Fig. 4). We provisionally interpret these observations as showing a steady-state DFM at stations $1,4,5,6,15,18$ and 19, on density surfaces with mean anomaly of 26.43 (s.d. 0.05). The data presented in the rest of this paper come from these 7 stations and from 3 others (D9, W40, D4.3) with similar properties sampled later in the cruise.

Fig. 5 compares extracted chlorophyll and fluorescence at example unperturbed stations. The chlorophyll values have been scaled using parameters from a linear regression of fluorescence on chlorophyll. The regression, determined for 28 samples from depths greater than $50 \mathrm{~m}$ at the unperturbed stations on the Long Section, was

fluorescence $(\mathrm{V})=a+b$ chlorophyll $\left(\mathrm{mg} \mathrm{m}^{-3}\right)$,

$a=0.07$ (s.e. $=0.01)(\mathrm{V})$,

$b=0.41($ s.e. $=0.03)\left(\mathrm{V} \mathrm{mg}^{-1} \mathrm{~m}^{3}\right)$.

There was more extractable chlorophyll above the DFM than suggested by fluorescence, and this was true of all stations examined. The smaller output of stimulated fluorescence per unit chlorophyll might be due to differences in dominant phytoplankters between the DFM and the overlying water, or to depression of fluorescence yield by sunlight or nutrient depletion (Setser et al., 1982; Droop, 1985; Pingree and Harris, 1988; Cunningham, 1996) in near-surface waters. Clearly, a simple function such as that of Eq. (1) can only provide an approximate conversion of fluorescence to chlorophyll profiles. Nevertheless, there is no doubt that the DFM was also a deep chlorophyll maximum. 
The peak fluorescence of the DFM increased about four-fold from west to east at these unperturbed stations in 1999; the increase in August 1993 was smaller. Our main interest in the present paper is, however, the depth, rather than the peak fluorescence or chlorophyll content, of the DFM and DCM. In 1999, the depth decreased from $110 \mathrm{~m}$ at station 1 to $40 \mathrm{~m}$ at station 19 (Fig. 4(a)). In 1993 the comparable range was from 110 to $50 \mathrm{~m}$ (Fig. 3(c).

Comparison of nutrient and fluorescence profiles (Fig. 5), and plots of $\mathrm{TO}_{\mathrm{x}} \mathrm{N}$ against density anomaly (Fig. 6) show that the DFM lay at the top of the nitracline. We define the upper and lower limits of the DFM as the least and greatest depths at which fluorescence was $50 \%$ or more of the maximum in a given profile. In the case of the stations that we interpret as steady state,

these limits were found at density anomalies of 26.29 (s.d. 0.10) and 26.51 (s.d. 0.03) $\mathrm{kg} \mathrm{m}^{-3}$. According to Fig. 6 this range corresponds to $\mathrm{TO}_{\mathrm{x}} \mathrm{N}$ concentrations of between 0.3 and $2 \mu \mathrm{M}$ (if what appear to be anomalous values are ignored).

The occurrence of the DFM-DCM at the top of the nitracline, corresponding to a constant isopycnal, suggests that the steady-state depth of the DCM is controlled by irradiance. The argument was set out in the Introduction. Competition for nutrients amongst populations of phytoplankters results in successful populations growing as close to the compensation depth as is possible given the need for some phytoplankton growth to offset losses due to grazing and eddy diffusion. And, in turn, it is the occurrence of the DCM that controls the relationship between the nitracline and density. The relationship is, however, likely to be complicated by two factors. The first is the local perturbations of the isopycnals, such as those caused by the islands. We avoid dealing with these by considering only unperturbed stations. The second is the zonal tilt in isopycnals caused by proximity to upwelling, and which might be expected to result in a shift in the nitracline to deeper (denser) isopycnals. Fig. 6 suggests that this shift is not marked. This is perhaps because water transparency decreases towards the east, tending to preserve the relationship between compensation depths and isopyncals.

\section{The DCM and the classical compensation depth}


In this section we will test the hypothesis that the depth of the peak of the DFM occurs just above the "classical" compensation depth, as defined in the Introduction. Because photosynthesis at low light is linearly related to irradiance, the classical compensation depth is approximately that at which $24 \mathrm{~h}$ mean irradiance is the compensation irradiance, and this irradiance is given by

$I_{\mathrm{c}}=\mathrm{r}_{0 \mathrm{a}} /\left(\chi_{\mathrm{a}} \alpha_{\mathrm{m}}\right),(2)$

where $r_{0 a}$ is the basal respiration rate of phytoplankton (that at zero growth) and $\alpha_{m}$ is the maximum photosynthetic efficiency. Because photosynthesis is dependent on chlorophyll, $\alpha_{\mathrm{m}}$ is best expressed in chlorophyll-related units. Respiration, however, is a function of biomass, and so better given in carbon-related units. Thus a term $\chi_{\mathrm{a}}$ for the phytoplankton chlorophyll:carbon ratio has been introduced into Eq. (1). Its value was taken as $0.4 \mathrm{mg} \mathrm{chl} \mathrm{(mmol} \mathrm{C)})^{-1}$ (Tett and Droop, 1988) on the grounds that phytoplankters at the compensation depth are, ex hypotheo, lightlimited and hence likely to have a relatively large pigment content. Goericke and Welschmeyer (1998) report a mean ratio corresponding to $0.36 \mathrm{mg} \mathrm{chl}(\mathrm{mmol} \mathrm{C})^{-1}$ at the $1.6 \%$ light level during an 18-month study south-east of Bermuda.

The respiration term was taken as $0.05 \mathrm{~d}^{-1}$, the standard phytoplankton value used in the model of Tett (1998) and based on the lower part of the range of values reported in the literature from studies (Laws and Caperon, 1976; Laws and Wong, 1978; Droop et al., 1982; Richardson et al., 1983 ) on cultured algae in which growth rate was set at, or extrapolated to, zero.

Values for photosynthetic efficiency were obtained from observations and the literature. Measurements (Table 1), made with samples from the unperturbed DCM in August 1999, averaged $0.044 \mathrm{mmol} \mathrm{C}(\mathrm{mg} \mathrm{chl})^{-1} \mathrm{~d}^{-1}\left(\mu \mathrm{Em}^{-2} \mathrm{~s}^{-1}\right)^{-1}$, corresponding to $I_{\mathrm{c}}$ of $2.8 \mu \mathrm{Em}^{-2} \mathrm{~s}^{-1}$. Values estimated in August 1993 (Basterretxea and Arístegui, 2000), had a mean of $0.050 \mathrm{mmol} \mathrm{C}$ (mg $\left.\mathrm{chl})^{-1} \mathrm{~d}^{-1}\left(\mu \mathrm{Em}^{-2} \mathrm{~s}\right)^{-1}\right)^{-1}$. Babin et al. (1996) report photosynthetic quantum yields $\Phi$ approaching 50 $\mathrm{nmol} \mathrm{C} \mu \mathrm{E}^{1}$ in the deeper part of oligotrophic water columns. Photosynthetic efficiency can be calculated from $\varepsilon \Phi$; in appropriate units, where $\varepsilon$ is photosynthetic pigment absorption cross- 
section corrected for the ability of phytoplankters to use photons from all angles: an appropriate value (Tett, 1990a) for clear oceans is $0.04 \mathrm{~m}^{-2}$ (mg chl) ${ }^{-1}$. The corresponding efficiency is 0.162 mmol C (mg chl) $)^{-1} \mathrm{~d}^{-1}\left(\mu \mathrm{Em}^{-2} \mathrm{~s}^{-1}\right)^{-1}$, corresponding to $I_{\mathrm{c}}$ of $0.8 \mu \mathrm{Em}^{-2} \mathrm{~s}^{-1}$.

Direct measurements of spectrally resolved submarine irradiance were available for hours close to mid-day at a few stations. In order to generalise these, we used a corrected PAR exponential decay equation (Tett, 1990a) to estimate compensation depth $z_{c}$

$I(\mathrm{z})=\mathrm{m} I_{0} \mathrm{e}^{-\mathrm{k} \cdot \mathrm{z}}=>$

$Z_{c}=\left(\operatorname{In}\left(m I_{0}\right)-\operatorname{In}\left(I_{c}\right)\right) / k$

where $I_{0}$ is 24-mean PAR just above the sea surface, $k$ is the attenuation coefficient of "most penetrating" downwelling diffuse PAR, and $m$ corrects for surface reflection and hyperexponential decay losses. The latter are the excess of PAR decay over simple exponential (Beer-Lambert) decay of monochromatic light due to the greater attenuation of red and blue light compared with the attenuation of most-penetrating of $490 \mathrm{~mm}$.

$I_{0}$ for stations 1-19 was taken $559 \mu \mathrm{Em}^{-2} \mathrm{~s}^{-1}$ the mean value calculated from the ship's pyrrheliometer for 6-10 August 1999. In fact, the mean daily value fell from 629 to 488 as the ship sailed eastwards, but subsequent records showed no systematic relationship between proximity to upwelling and lower surface irradiance. The mean for the period 6-27 August was $568 \mu \mathrm{Em}^{-2} \mathrm{~s}^{-1}$ with a CV of $8 \%$.

During the entire cruise, spectroradiometer measurements were made at 32 stations, but only 6 of these were considered "unperturbed" as previously defined. Diffuse attenuation coefficients were estimated for these 6 unperturbed stations by regressing $\ln (\mathrm{PAR})$ on depth over the depth range from $20 \mathrm{~m}$ to the top of the DFM (defined as the depth at which fluorescence first reached $50 \%$ of the peak value). A relationship was then sought with CTD-fluorometer voltage averaged over the interval from $5 \mathrm{~m}$ to the top of the DFM, defined as the depth at which fluorescence reached $50 \%$ of the DFM peak, and this allowed $k$ to be prescribed at all unperturbed stations. The relationship was 
$k\left(\mathrm{~m}^{-1}\right)=a+b($ mean fluorescence, $\mathrm{V})\left(\mathrm{m}^{-1}\right)$,

$a=0: 023(\mathrm{se}=0.003)\left(\mathrm{m}^{-1}\right)$,

$b=0: 548(\mathrm{se}=0.039)\left(\mathrm{m}^{-1} \mathrm{~V}^{-1}\right)$.

The factor $m$ includes surface reflection losses and corrects for the hyperexponential decay of PAR near the sea surface because of rapid extinction of (in particular) red light and of the part of the photon flux that makes a large angle to the vertical. It was estimated by extrapolating the regressions of $\ln (\mathrm{PAR})$ on depth to the sea surface, and comparing this estimate of PAR with that calculated from the ship's pyrrheliometer. Five valid values obtained by this method gave $\mathrm{m}$ of 0.60 (s.d. 0.07). The value obtained by this method also corrects for inaccuracies in the spectroradiometer's calibration compared with that of the ship's pyrrheliometer, including the effects of assumptions about energy to quanta ratios. Such calibration errors however, were, small. The PAR recorded by the spectroradiometer just above the sea-surface was compared with the PAR quantum flux calculated from the ship's pyrrheliometer at the same time. Ten such comparisons included a minimum ratio (pyrrheliometer:radiometer) of 1.08, and median of 1.19. Ratios a little above unity are not surprising, given the partial obscuring of the radiometer's field of view by the ship's superstructure.

The procedure for estimating $k$ and $m$ aimed to avoid the errors introduced into PAR measurements in the upper $20 \mathrm{~m}$ of the water column by proximity to the ship. It is possible that the value of $m$ estimated from observations within a few hours of mid-day, was higher than the $24 \mathrm{~h}$ mean value, since the latter would include the greater losses at times of low sun angle. However, a large proportion of total photons arrives in the $6 \mathrm{~h}$ around mid-day, and as the photosynthesis model employed to estimate the compensation depth is a linear-response or photon-accumulating model, no further correction was made to $m$ : It was considered that such corrections would have been relatively small and within the standard error of the estimate of the value of the factor.

Fig. 7 compares estimates of the compensation depth from Eq. (2) with the observed depth of the DFM at unperturbed stations in August 1999. The "classical" theory, with compensation 
irradiance, $I_{c}$; in the range $0.8-2.8 \mu \mathrm{Em}^{-2} \mathrm{~s}^{-1}$, predicts that the DFM should occur much deeper than it did. In order to obtain agreement between predicted compensation depths and observed DFM depths, compensation irradiance must be in the range $10-20 \mu \mathrm{Em}^{-2} \mathrm{~s}^{-1}$.

\section{The microplankton compensation depth}

The "classical theory", based on a basal phytoplankton respiratory loss rate of $0.05 \mathrm{~d}^{-1}$, leads to compensation irradiances that are too little. Is it possible that algal basal respiration, r0a in Eq. (2), might be larger than $0.05 \mathrm{~d}^{-1}$ ?

There were higher values in the data from algal cultures reviewed by Tett (1998), but basal respiration is difficult to measure and is easier to overestimate than to underestimate. In the rest of this paper, therefore, we explore the alternative hypothesis that the true compensation irradiance is higher than the "classical" value because the phytoplankton of the DCM have to sustain steady-state losses additional to their own respiration. These losses are those due to the “microbial loop”, mesozooplankton grazing, sinking, and vertical turbulent diffusion.

The "microbial loop" (Williams, 1981; Azam et al., 1983) describes the processes by which organic carbon produced by the photosynthesis of phytoplankton passes to pelagic microheterotrophs-bacteria and protozoa. As described above, Tett (1990b) and Tett and Walne (1995) parameterised the microbial loop as a "microplankton" compartment containing algae, photosynthetic and heterotrophic bacteria, and protozoa. The parameterisation has been developed (Tett, 1998; Smith and Tett, 2000; Tett and Wilson, 2000) into a set of equations that relates microplankton bulk parameters explicitly to autotroph and heterotroph parameters using the "heterotroph fraction" $y$, the ratio of the biomass of heterotrophic bacteria and protozoans to the total biomass of the microplankton (which also includes phytoplankton). For present purposes, the key features of the microplankton model are (i) the assumption, for given conditions, of a constant value of $\mathrm{y}$; (ii) the inclusion in respiration of a microplankton-growthrate related component as well as a basal component'; (iii) the dependence of the microplankton 
chlorophyll content $\mathrm{w}$ on the microplankton cell nitrogen content $Q$; and (iv) that nutrientnitrogen uptake is a saturation function of sea-water dissolved available nitrogen concentration, inhibited by increasing internal nitrogen content.

Two key equations describe the rate of change of microplankton nitrogen content

$\partial Q / \partial t=u-\mu Q-\Delta \varphi_{Q}\left(\operatorname{mol~N}(\mathrm{mol} \mathrm{C})^{-1}\right)$.

and the rate of change of microplankton carbon biomass concentration:

$\partial B / \partial t=(\mu-G) B-\Delta \varphi_{B}\left(\mathrm{mmol} \mathrm{Cm}^{-3} \mathrm{~d}^{-1}\right)$.

In Eq. (6), microplankton growth rate $\mathrm{m}$ is a threshold function of light and internal nutrient $\mu=\min \{(\alpha \chi I-r), f(Q)\}\left(d^{-1}\right)$.

and the flux divergence term can be expanded, as exemplified here, for the vertical direction only (denoting vertical flux as $\varphi_{\mathrm{B}}$ )

$$
\begin{aligned}
& \Delta \varphi_{\mathrm{B}}=\partial \varphi \mathrm{B} / \partial \mathrm{z} \\
& =-K z \partial B / \partial z-{ }_{w B} B\left(m m o l \mathrm{Cm}^{-2} \mathrm{~d}^{-1}\right) \text {. }
\end{aligned}
$$

In the case of an analysis of the steady-state dynamics of the deep chlorophyll maximum, the rates of change in Eqs. (7) and (8) can be set to zero, and we assume that the flux divergence of $Q$ is also zero. Using the expansions of the microplankton equations given by Tett (1998), the equation set can be manipulated to give the following solutions for the compensation irradiance in a steady state

$$
\begin{aligned}
& I_{\mathrm{c}}=\left(L(1+b)+\mathrm{r}_{0}\right) /(\alpha \chi)\left(\mu \mathrm{Em}^{-2} \mathrm{~s}^{-1}\right), \\
& \mathrm{r}_{0}=\mathrm{r}_{0 \mathrm{a}}(1-\mathrm{y})+\mathrm{r}_{0 \mathrm{~h}} \mathrm{~g}\left(1+b_{\mathrm{a}}\right)\left(\mathrm{d}^{-1}\right) \\
& b=b_{\mathrm{a}}\left(1+b_{\mathrm{h}} \mathrm{\eta}\right)+b_{\mathrm{h}} h: \mu>0 \\
& \chi={ }^{\mathrm{x}} q_{\mathrm{a}}^{\mathrm{N}}\left(Q-q_{h} \mathrm{y}\right)\left(\mathrm{mg} \operatorname{chl}(\mathrm{mmol} \mathrm{C})^{-1}\right) \text {, } \\
& Q=1 /\left(y^{-1}+Q_{\text {max }}^{-1}\right): Q \geq Q_{\text {min }} \\
& \left(\mathrm{mmol} \mathrm{N}(\mathrm{mmol} \mathrm{C})^{-1}\right) \text {, } \\
& y=u_{\max }\left(\mathrm{S} /\left(k_{\mathrm{S}}+S\right)\right) \text {, } \\
& Q_{\max }=Q_{\max }(1-\mathfrak{y})+q_{\mathrm{h}} \mathrm{y} \text {, }
\end{aligned}
$$


$\mathrm{L}=\mathrm{B}^{-1} \partial \varphi_{\mathrm{B}} / \partial \mathrm{z}+G\left(\mathrm{~d}^{-1}\right)$

$\varphi B=-K_{z} \partial_{B} / \partial z-w_{B} B\left(m m o l m^{-2} d^{-1}\right)$.

The losses due to mesozooplankton grazing and the vertical flux divergence, are summarised in Eq. (13) by the relative loss rate $L$. Table 2 defines all symbols and gives the parameter values used in the calculation of the compensation irradiance. Most of the values have been derived from Tett (1998), but uptake rate has been adjusted for the likely small size of organisms in the oceanic DCM.

As presented in Eqs. (9)-(12), the solution to this steady-state model for the compensation irradiance depends on three variables that do not have predefined values. They are: the sea-water dissolved available nitrogen concentration $S$, the "external" loss rate $L$, and the heterotroph fraction $\mathrm{y}$. Because the microplankton of the model are supposed to recycle all ammonium within the microbial loop, $S$ will be equated with the measurements of nitrate+nitrite. Fig. 8 gives predictions of the compensation irradiance $I_{\mathrm{c}}$ as a function of $S, L$ and $\mathrm{y}$. The observations of $\mathrm{TO}_{\mathrm{x}} \mathrm{N}$ (Fig. 6) put $S$ in the range from 0.3 to $2 \mathrm{mmol} \mathrm{m}^{-3}$ in the DCM, and suggest a range of values of the compensation irradiance between 3 and $20 \mu \mathrm{E} \mathrm{m}^{-2} \mathrm{~s}^{-1}$ for values of the heterotroph fraction between 0.2 and 0.5 and external loss rates $L$ of $0.05-0.20 \mathrm{~d}^{-1}$. As Fig. 7 shows, the best agreement between the depth of the DCM and the compensation depth was obtained for $I_{\mathrm{c}}$ of 10 $20 \mu \mathrm{E} \mathrm{m}^{-2} \mathrm{~s}^{-1}$.

The main set of parameter values for the microplankton model MP is considered welldefined, following several sensitivity studies and applications (Tett et al., 1993; Tett and Grenz, 1994; Tett and Walne, 1995; Tett, 1998; Smith and Tett, 2000; Tett and Wilson, 2000). However, several parameter values may be sensitive to the typical size of the simulated microplankters, or are less well known. Tett (1998) found a median value of $2.2 \mathrm{mg} \mathrm{chl}(\mathrm{mmol} \mathrm{N})^{-1}$ for the chlorophyll yield $X_{\mathrm{q}} N_{\mathrm{a}}$ in published accounts of work in single-species algal cultures, but adjusted the value to the current standard of 3.0 to provide a better fit of data from a microcosm experiment in which the dominant photoautotrophs were diatoms. MP's standard value for the 
maximum uptake rate of nitrate, $u_{\max }$ a, is $0.5 \mathrm{mmol} \mathrm{N}(\mathrm{mmol} \mathrm{C})^{-1} \mathrm{~d}^{-1}$. This was adjusted to 1.67 (Table 2), on the grounds that uptake is a property of the surface of cells and that typical microorganisms were small in the DCM in Canaries waters (Barton et al., 1998). Autotroph basal respiration, $\mathrm{r}_{0 \mathrm{a}}$, was not so adjusted. Had it been, the value of $0.05 \mathrm{~d}^{-1}$ would have become 0.167 $\mathrm{d}^{-1}$. In fact, the model's prediction of compensation irradiance is rather insensitive to such changes (Fig. 9).

\section{6. "External"' losses}

"External" means a process taking place outside of the model's microplankton compartment. The "external" loss term $L$ is shown by Eq. (13) to include the effects of mesozooplankton grazing, vertical mixing, and sinking. The results of a modelling study of the DCM at an oligotrophic site at $301 \mathrm{~N}, 161 \mathrm{~W}$, about $100 \mathrm{~km}$ north of the Canary Islands (Wild, 1995) suggested that: the best estimate of eddy diffusion coefficient $\mathrm{Kz}$ in the upper thermocline was $1.1 \mathrm{~m}^{-2} \mathrm{~d}^{-1}$; microplankton sinking rates were in the range $0-2 \mathrm{~m} \mathrm{~d}^{-1}$, with lowest values in the DCM; and mesozooplankton grazing pressure $G$ in a typical August was $0.08 \mathrm{~d}^{-1}$. These were the values that gave best agreement between observed and simulated deep chlorophyll maxima. The value of the diffusion coefficient was within the range of $0.01-0.25 \mathrm{~cm}^{-2} \mathrm{~s}^{-1}$ reported for the upper $150 \mathrm{~m}$ an oligotrophic station in the eastern North Atlantic by Lewis et al. (1986). The grazing pressure was derived from observed mesozooplankton abundance (Hernández-León et al., 1984; Hernández-León, 1988a, b) and an adjustable copepod volume-clearance rate.

During the cruise in August 1993 (Barton et al., 1998), as yet unpublished estimates of mesozooplankton grazing pressure were made by one of us (Hernandez-León) from (i) the fluorescence of phytoplankton pigments in copepod guts, and (ii) estimates of mesozooplankton metabolic demand. The gut fluorescence method, which indicates feeding on phytoplankton only, gave a mean daily consumption of about $10 \%$ of the measured primary production of about 200 $\mathrm{mg} \mathrm{C} \mathrm{m} \mathrm{d}^{-1}$. The metabolic demand method, which includes feeding on microplankton heterotrophs, suggested a higher consumption, up to $30 \%$ of measured primary production. 
These results are averages over all stations, and hence do not distinguish "perturbed" from "unperturbed" stations. The detailed profiles that contribute to the averages, suggest some concentration of mesozooplankton feeding effort at the depth of the DCM. It seems likely that daily primary production was about $20 \%$ of microplankton biomass, on the basis of observed column-integrated chlorophyll data and a presumed mean chlorophyll:carbon ratio of $0.02 \mathrm{mg}$ $(\mathrm{mg})^{-1}$, and hence an upper estimate of grazing pressure $\mathrm{G}$ is $0.06 \mathrm{~d}^{-1}$.

In August 1993, the DCM was dominated by small phytoflagellates according to microscopy (Barton et al., 1998); according to HPLC pigment analysis, prochlorophytes also played a part. It seems likely that these small (and, in some cases, mobile) organisms do not contribute a significant sinking flux, given their size and the demonstration that the DCM was found in 1999 on isopycnals where there adequate nutrients.

Relative mixing losses from both sides of the deep chlorophyll maximum were calculated from $\left(\partial \varphi_{\mathrm{B}} / \partial \mathrm{z}\right) B^{-1} \approx 4\left(K_{\mathrm{z}} \Delta \ln (X) / \Delta \mathrm{z}\right) / l_{\mathrm{v}}\left(\mathrm{d}^{-1}\right)$.

The relative gradient of phytoplankton was estimated from the mean gradient $\Delta \ln (X) / \Delta z$ of the logarithm of fluorescence on either side of the DCM. The thickness $l_{\mathrm{v}}$ of the DCM was taken from the interval between the upper and lower depths of $50 \%$ fluorescence. The vertical eddy coefficient $K_{\mathrm{z}}$ was taken as $1.1 \mathrm{~m}^{-2} \mathrm{~d}^{-1}$ from the modelling results of Wild (1995). Estimates of the mixing loss varied from less than $0.01 \mathrm{~d}^{-1}$ in the case of the westernmost station 1 , to $0.08 \mathrm{~d}^{-1}$ at the easternmost unperturbed station 19. The most common values for the unperturbed stations on the section of 6-10 August 1999 were 0.01 or $0.02 \mathrm{~d}^{-1}$.

These very preliminary results suggest that values of $L$ were between 0.03 and $0.16 \mathrm{~d}^{-1}$. A loss rate at the lower end of this range would necessitate a value of the heterotroph fraction $y$ of at least 0.6 for the compensation irradiance $I_{\mathrm{c}}$ to be in the range of $10-20 \mu \mathrm{Em}^{-2} \mathrm{~s}^{-1}$ (Fig. 8) that is most in agreement with the observations of the depth of the DFM (Fig. 7). Conversely, an 
external loss rate of $0.5 \mathrm{~d}^{-1}$ is required to ensure $I_{\mathrm{c}}>10 \mu \mathrm{Em}^{-2} \mathrm{~s}^{-1}$ for $\mathrm{\eta}=0$.

\section{Discussion and conclusions}

Our assumption that the occurrence of the DFM on a particular isopycnal may be used to identify "unperturbed" stations, for analysis in terms of steady state theory, could be considered a weakness. Cullen and Eppley (1981) found that the "density structure of the water column does not have overriding proximate control on the position of chlorophyll maxima ...'. However, they were analysing data taken during 5 years and under a range of conditions. In contrast, Letelier et al. (1993) reported that, although the potential density associated with the DCM changed substantially during their 3-year study near Hawaii, $\sigma \Theta$ at the DCM remained constant during a given cruise.

The main aim of this paper has been to show that although the depth of the DCM at unperturbed stations can be explained by compensation depth theory, it is not enough to look for the depth at which gross photosynthesis is balanced by phytoplanktonic respiration alone. As foreseen by Sverdrup (1953) it is necessary to take into account additional losses. Our argument is, however, that losses due to consumption by the pelagic microheterotrophs of the microbial loop are at least as important as losses to mixing and mesozooplankton grazing. Table 3 contrasts two extreme scenarios that both give a value of $10 \mu \mathrm{Em}^{-2} \mathrm{~s}$ for the compensation irradiance $I_{\mathrm{c}}$ : Scenario A assumes a microbial-loop community of which $60 \%$ are microheterotrophs. The photon energy that is harnessed to maintain the microplankton community in equilibrium, is shared mainly between autotrophs and microheterotrophs, with only $20 \%$ going to mesozooplankton. Scenario $\mathrm{B}$ ignores the microbial loop and supposes that mesozooplankton feed directly on phytoplankton. In this more dynamic scenario, mesozooplankton take more than half the captured photon energy. The value of mesozooplankton grazing loss used in scenario $\mathrm{A}$ is that derived in the preceeding section. The grazing loss of $0.40 \mathrm{~d}^{-1}$ used in scenario $\mathrm{B}$ is that required to give the required compensation irradiance, and is much higher than suggested by studies of pelagic grazing in Canaries waters. 
As used here, the term "microplankton" refers to all pelagic Protoctista and bacteria passing a $200 \mu \mathrm{m}$ screen, and the microplankton model parameterises their metabolic demands as a bulk respiration rate which opposes the photosynthesis of the autotrophic component of the microplankton. The model assumes a constant balance, for given conditions, between microplankton autotrophs and heterotrophs. In order to sustain this balance and provide for microheterotroph as well as autotroph respiration at the microplankton compensation depth, the phytoplankton component must have a positive growth rate. This deduction provides a basis for the calculation of microplankton compensation respiration $r_{0}$, in Eq. (10).

There are other ways of introducing the demands of pelagic microheterotrophs into calculations of compensation depth, but the model presented here has the advantage of allowing a steady state solution in terms of the "external" variables $L$ and $S$ as well as the "internal" microplankton parameter $\mathrm{y}$. Nutrient concentrations $\mathrm{S}$ were measured. Our basic assumption is that the DCM should be found at or just above the microplankton compensation depth. If this is correct, then we may use the conclusion that the microplankton compensation irradiance lies in the range 10 $20 \mu \mathrm{Em}^{-2} \mathrm{~s}^{-1}$ for unperturbed Canary Islands waters in order to deduce likely values of $\mathrm{y}$. For low external losses, the heterotroph fraction must be relatively large, at least 0.6. For more likely external losses, between 0.1 and $0.2 \mathrm{~d}^{-1}$, the fraction should be in the range 0.3-0.6. A mean value of $y$ of 0.45 can be calculated from biomass data for "open ocean" conditions reviewed by Gasol et al. (1997), so values between 0.3 and 0.6 are not unreasonable. This view agrees with the assumption of Lenz et al. (1993) that at $341 \mathrm{~N} 211 \mathrm{~W}$, "nanozooplankton grazing played an important role in keeping phytoplankton standing stock in a quasi-steady-state" in April 1989.

In the absence of data about local microheterotrophic activity, our conclusion, that the unexpectedly shallow DFM-DCM is largely the result of the additional respiration of pelagic microheterotrophs, is only the most plausable of the alternatives (which include higher grazing by mesozooplankton and more respiration by phytoplankters). The deduction that the heterotroph fraction in the DFM-DCM should be in the range 0.3-0.6, can be seen as a testable prediction of the model, requiring detailed microscopic examination of DCM water samples. It is also verifiable in a different way, as the model can be used to make predictions of the relationship 
between chlorophyll and microplankton oxygen demand at steady state DCMs.

\section{Acknowledgements}

We are grateful to the European Commission for funding from the MAST 0031 and CANIGO projects, to the Spanish Comision Interministerial de Ciencia y Tecnología for the provision of ship time, and for assistance by the captains and crews of B.I.O. Hesperides and the technical staff of UGBO.

\section{References}

Agusti, S., Duarte, C.M., 1999. Phytoplankton chlorophyll a distribution and water column stability in the central Atlantic Ocean. Oceanologica Acta 22, 193-203.

Aristegui, J., Tett, P., Hernandez-Guerra, A., Basterretxea, G., Montero, M.F., Wild, K., Sangrá, P., Hernández-León, S., Cantón, M., García-Braun, J.A., Pacheco, M., Barton, E.D., 1997. The influence of island-generated eddies on chlorophyll distribution: a study of mesoscale variation around Gran Canaria. Deep-Sea Research I 44, 71-96.

Azam, F., Fenchel, T., Field, J.G., Gray, J.S., Meyer-Reil, L.A., Thingstad, F., 1983. The ecological role of watercolumn microbes in the sea. Marine Ecology—Progress Series 10, $257-263$.

Babin, M., Morel, A., Claustre, H., Bricaud, A., Kolber, Z., Falkowski, P.G., 1996. Nitrogen-and irradiance-dependent variations of the maximum quantum yield of carbon fixation in eutrophic, mesotrophic and oligotrophic marine systems. Deep-Sea Research I 43, 1241-1272.

Barton, E.D., E.D., Arístegui, J., Tett, P., Cantón, M., García-Braun, J.A., Hernández-Leon, S.,

Nykjaer, L., Almeida, C., Almunia, J., Ballasteros, S., Basterretxea, G., Escánez, J., GarcíaWeill, J., Hernández-Guerra, A., López-Laatzen, F., Molina, R., Montero, M.F., NavarroP!erez, E., Rodríguez- Pérez, J.M., van Leening, K., Velez, H., Wild, K., 1998. The transition zone of the Canary Current upwelling region. Progress in Oceanography 41, 457-503.

Basterretxea, G., Aristegui, J., 2000. Mesoscale variability in phytoplankton biomass distribution and photosynthetic parameters in the Canary-NW African coastal transition zone. Marine 
Ecology—Progress Series 197, 21-40.

Cullen, J.J., 1982. The deep chlorophyll maximum: comparing vertical profiles of chlorophyll a. Canadian Journal of Fisheries and Aquatic Science 39, 791-803.

Cullen, J.J., Eppley, R.W., 1981. Chlorophyll maximum layers of the Southern California Bight and possible mechanisms of their formation and maintenance. Oceanologica Acta 4, 23-32.

Cunningham, A., 1996. Variability of in-vivo chlorophyll fluorescence and its implication for instrument development in bio-optical oceanography. Scientia Marina 60, 309-315.

Droop, M.R., 1985. Fluorescence and the light-nutrient interaction in Monochrysis. Journal of the Marine Biological Association of the United Kingdom 65, 221-237.

Droop, M.R., Mickelson, M.J., Scott, J.M., Turner, M.F., 1982. Light and nutrient status of algal cells. Journal of the Marine Biological Association of the United Kingdom 62, 403-434.

Eppley, R.W., 1972. Temperature and phytoplankton growth in the sea. United States Fisheries and Wildlife Service Bulletin 70, 1063-1085.

Fasham, M.J.R., Platt, T., Irwin, B., Jones, K., 1985. Factors affecting the spatial pattern of the deep chlorophyll maximum in the region of the Azores front. Progress in Oceanography 14, $129-165$.

Gasol, J.M., del Giorgio, P.A., Duarte, C.M., 1997. Biomass distribution in marine planktonic communities. Limnology and Oceanography 42, 1353-1363.

Goericke, R., Welschmeyer, N.A., 1998. Response of Sargasso Sea phytoplankton biomass, growth rates and primary production to seasonally varying physical forcing. Journal of Plankton Research 20, 2223-2249.

Hernandez-Leon, S., 1988a. Ciclo anual de la biomasa del mesozooplancton sobre una area de plataforma en aguas del Archipelago Canario. Investigacion Pesqueria 52, 3-16.

Hernandez-Leon, S., 1988b. Gradients of mesozooplankton biomass and ETS activity in the wind-shear area as evidence of an island mass effect in Canary Island waters. Journal of Plankton Research 10, 1141-1154.

Hernandez-Leon, S., Llinas, O., Braun, J.G., 1984. Nota sobra variacion de la biomasa del mesozooplancton en aguas de las Islas Canarias. Investigacion Pesqueria 48, 495-508.

Holm-Hansen, O., Lorenzen, C.F., Homes, R.W., Strickland, J.D.H., 1965. Fluorimetric determination of chlorophyll. Journal du Conseil permanent international pour 1'Exploration 
de la Mer 30, 3-15.

Laws, E., Caperon, J., 1976. Carbon and nitrogen metabolism by Monochrysis lutheri: measurement of growth-rate-dependent respiration rates. Marine Biology 36, 85-97.

Laws, E.T., Wong, D.C.L., 1978. Studies of carbon and nitrogen metabolism by three marine phytoplankton species in nitrate-limited continuous culture. Journal of Phycology 14, 406416.

Legendre, L., Rassoulzadegan, F., 1995. Plankton and nutrient dynamics in marine waters. Ophelia 41, 153-172.

Lenz, J., Morales, A., Gunkel, J., 1993. Mesozooplankton standing stock during the North Atlantic spring bloom study in 1989 and its potential grazing pressure on phyytoplankton: a comparison between low, medium and high latitudes. Deep-Sea Research II 40, 559-572.

Letelier, R.M., Bidigare, R.R., Hebel, D.V., Ondrusek, M., Winn, C.D., Karl, D.M., 1993. Temporal variability of phytoplankton community structure based on pigment analysis. Limnology and Oceanography 38, 1420-1437.

Lewis, M.R., Harrison, W.G., Oakey, N.S., Herbert, D., Platt, T., 1986. Vertical nitrate fluxes in the oligotrophic ocean. Science 234, 870-873.

Lindholm, T., 1992. Ecological role of depth maxima of phytoplankton. Archiv fur Hydrobiologie, Ergebnisse der Limnologie 35, 33-45.

Margulis, L., 1993. Symbiosis in Cell Evolution: Microbial Communities in the Archaean and Proterozoic eons, 2nd Edition. W.H. Freeman and Co., New York, xxiv + 452 pp1.

Marshall, S.M., Orr, A.P., 1928. The photosynthesis of diatom cultures in the sea. Journal of the Marine Biological Association of the United Kingdom 15, 321-360.

Oudot, C., Montel, Y., 1988. A high sensitivity method for the determination of nanomolar concentrations of nitrate and nitrite in sea water with a technicon auto analyzer II. Marine Chemistry 24, 239-252.

Pingree, R.D., Harris, R.P., 1988. An in vivo fluorescence response in the Bay of Biscay in June. Journal of the Marine Biological Association of the United Kingdom 68, 519-529.

Richardson, K., Beardall, J., Raven, J.A., 1983. Adaptation of unicellular algae to irradiance: an analysis of strategies. New Phytologist 93, 157-191.

Setser, P.J., Guinasso, N.L.J., Schink, D.R., 1982. Daily patterns of fluorescence in vivo in the 
central equatorial Pacific. Journal of Marine Research 40, 453-471.

Smetacek, V., Passow, U., 1990. Spring bloom initiation and Sverdrup's critical-depth model. Limnology and Oceanography 35, 228-234.

Smith, C.L., Tett, P., 2000. A depth resolving numerical model of physically forced microbiology at the European shelf edge. Journal of Marine Systems 26, 1-36.

Sverdrup, H.U., 1953. On conditions for the vernal blooming of phytoplankton. Journal du Conseil 18, 237-295.

Tett, P., 1987. The ecophysiology of exceptional blooms. Rapport et Proces-verbaux des Reunions, Conseil international pour l'Exploration de la Mer 187, 47-60.

Tett, P., 1990a. The Photic Zone. In: Herring, P.J., Campbell, A.K., Whitfield, M., Maddock, L. (Eds.), Light and Life in the Sea. Cambridge University Press, Cambridge, UK, pp. 59-87.

Tett, P., 1990b. A three layer vertical and microbiological processes model for shelf seas. Proudman Oceanographic Laboratory Report, 14, Proudman Oceanographic Laboratory, Birkenhead, UK, 85 pp.

Tett, P., 1998. Parameterising a microplankton model. Report, Napier University, Edinburgh, 54+ix pp. In: Luyten, P.J., Jones, J.E., Proctor, R., Tabor, A., Tett, P., Wild-Allen, K., COHERENS-A Coupled Hydrodynamical-Ecological Model for Regional and Shelf Seas, CD-ROM, Managment Unit of the Mathematical Models of the North Sea (MUMM), Brussels, 1999.

Tett, P., Droop, M.R., 1988. Cell quota models and planktonic primary production. In: Wimpenny, J.W.T. (Ed.), Handbook of Laboratory Model Systems for Microbial Ecosystems., Vol. 2. CRC Press, Florida, pp. 177-233.

Tett, P., Grenz, C., 1994. Designing a simple microbiologicalphysical model for a coastal embayment. Vie et Milieu 44, 39-58.

Tett, P., Walne, A., 1995. Observations and simulations of hydrography, nutrients and plankton in the southern North Sea. Ophelia 42, 371-416.

Tett, P., Wilson, H., 2000. From biogeochemical to ecological models of marine microplankton. Journal of Marine Systems 25, 431-446.

Tett, P., Edwards, A., Grantham, B., Jones, K., \&Turner, M., 1988. Microplankton dynamics in an enclosed coastal water column in summer. In: Round, F.E. (Ed.), Algae and the Aquatic 
Environment (Contributions in honour of J.W.G. Lund, F.R.S.). Biopress, Bristol, UK, pp. 339-368.

Tett, P., Joint, I., Purdie, D., Baars, M., Oosterhuis, S., Daneri, G., Hannah, F., Mills, D.K., Plummer, D., Pomroy, A., Walne, A.W., Witte, H.J., 1993. Biological consequences of tidal stirring gradients in the North Sea. Philosophical Transactions of the Royal Society of London A340, 493-508.

Treguer, P., Le Corre, P., 1975. Manuel d' Analyse des Sels Nutritifs dans l' Eau de Mer., Utilisation de l' Autoanalyzer II Technicon (R). 2"eme Edition. Brest, Laboratoire d' Oceanologie Chimique, Universit!e de Bretagne Occidentale.

Webb, W.L., Newton, M., Starr, D., 1974. Carbon dioxide exchange of Alnus rubrus: a mathematical model. Oecologia 17, 281-291.

Wild, K.A., 1995. The deep chlorophyll maximum near the Canary Islands (Spain). Ph D. Thesis, University of Wales, Bangor, xvi+255 pp.

Williams, P.J.1., 1981. Incorporation of microheterotrophic processes into the classical paradigm of the plankton food web. Kieler Meeresforschungen 5, 1-28. 


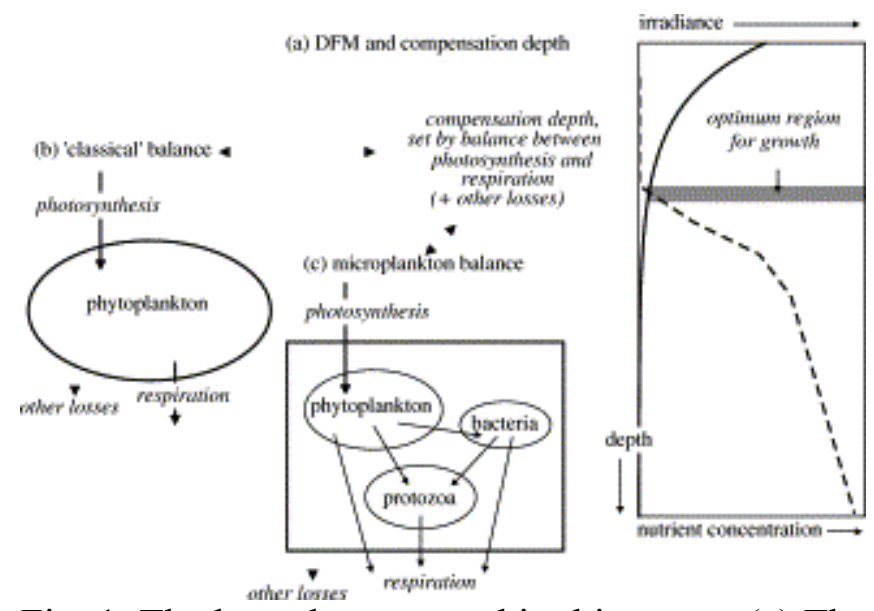

Fig. 1. The hypotheses tested in this paper: (a) The DCM occurs in a zone just above the compensation depth in which there is an adequate supply of nutrients. The compensation depth is the depth at which the $24 \mathrm{~h}$ mean PAR is the compensation irradiance $I_{c}$. (b) In the "classical" model, $I_{c}$ results from the balance between photosynthesis and respiration of phytoplankters only. (c) In the "microplankton" model, $I_{\mathrm{c}}$ results from the balance between the photosynthesis of phytoplankters and the respiration of all microbial loop organisms.

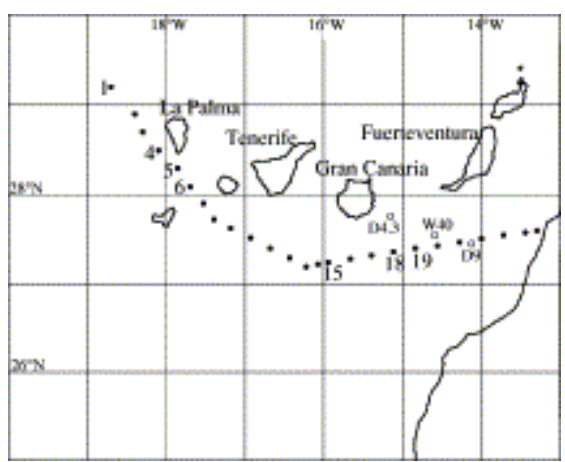

Fig. 2. Map of Canary Islands waters, showing the stations worked between 6 and 10 August 1999 on the standard Long Section of Barton et al. (1998). Numbered points are stations at which the deep chlorophyll maximum was deemed to be unperturbed. Three later, unperturbed, stations from which optical data are used, are also shown. 

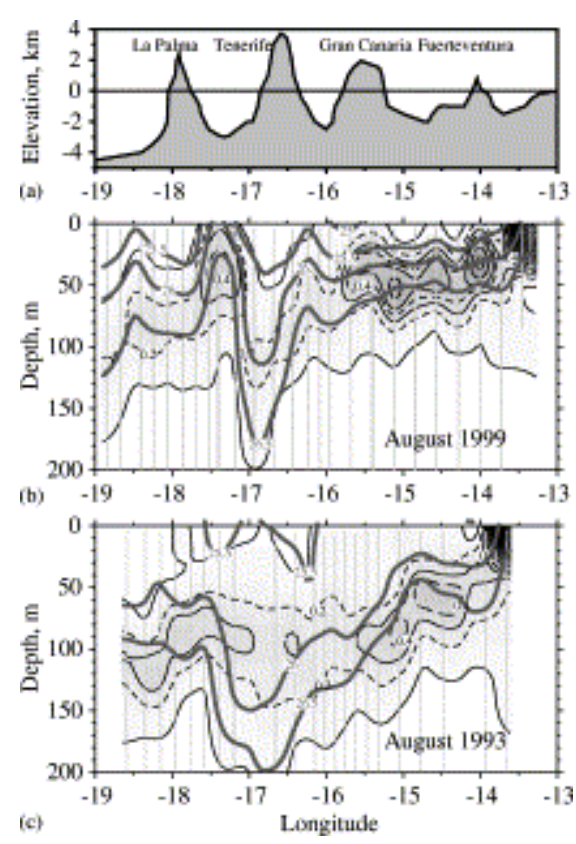

Fig. 3. The Long Section through Canary Islands waters, showing: (a) island profiles; and sections for (b) August 1999 and (c) August 1993; ((c) after Barton et al., 1998). The sections show contours of the density anomaly $\left(\mathrm{kg} \mathrm{m}^{-3}\right)$ (thick lines) overlaid on contours of fluorometer voltage (thin lines and shading).
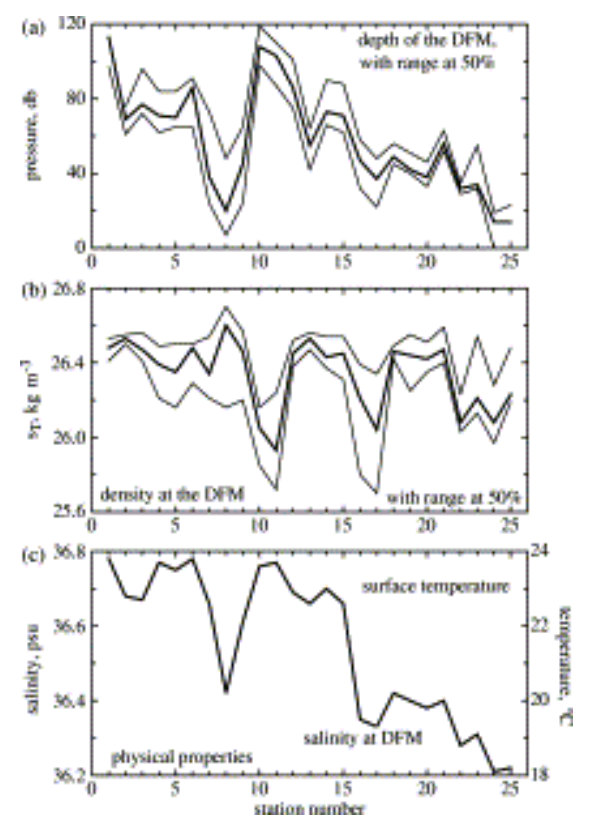

Fig. 4. Statistics for the deep fluorescence maximum (DFM) on the Long Section of Fig. 2. In (a) and (b) the upper and lower limits are at 50\% of maximum fluorescence: (a) Pressure at which the DFM was found (depth in metres is, approximately, 0.97 of the pressure in decibars). (b) The density anomaly at the DFM. (c) Other physical properties. The influence of the north-west African coastal upwelling is shown by colder water and reduced DFM salinity in the eastern part of the section. 


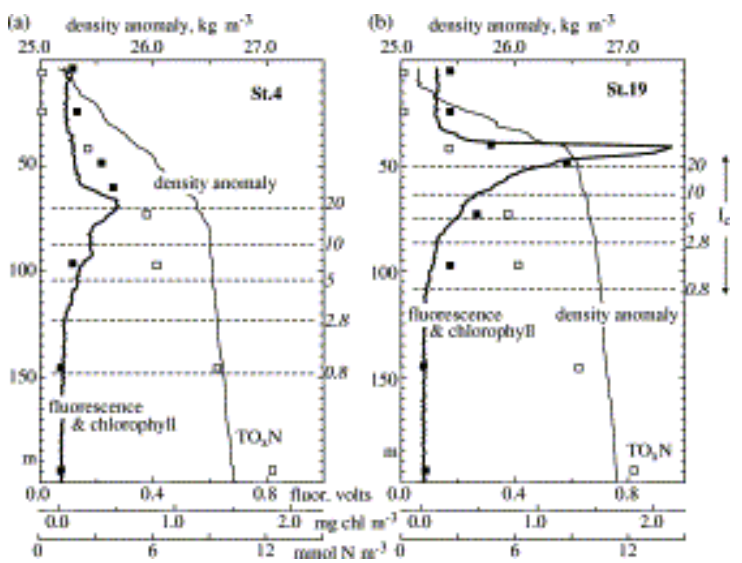

Fig. 5. Profiles of CTD-measured density anomaly and fluorescence at selected unperturbed stations on the long section of Fig. 2. Symbols show water-sampled chlorophyll and total oxidised nitrogen $\left(\mathrm{TO}_{x} \mathrm{~N}\right.$ : nitrate+nitrite). See text concerning the relationship between chlorophyll and fluorescence. Horizontal lines show the compensation depths corresponding to several values of the compensation irradiance. (a) Station 4 on 7 August 1999. (b) station 19 on 9 August 1999.

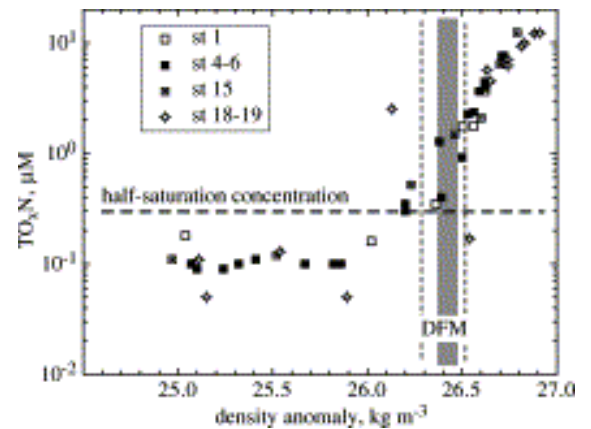

Fig. 6. Plots of total oxidised nitrogen $\left(\mathrm{TO}_{x} \mathrm{~N}\right.$, nitrate+nitrite) concentration (geometric scale), for unperturbed stations, against density anomaly. The dashed horizontal line is a typical value of $k_{S}$, the nutrient concentration at which phytoplankton nitrate uptake is half-saturated. The stippled area is the range of density anomalies at which the DFM occurred. The vertical dashed lines show the mean densities between which fluorescence was $50 \%$, or more, of its maximum value in a given profile. 


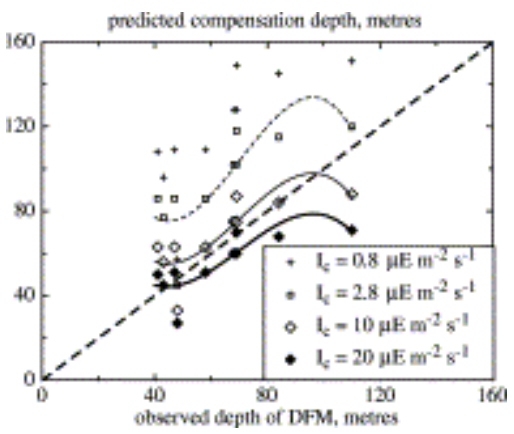

Fig. 7. Compensation depths predicted using Eq. (3) from 4 values of the compensation irradiance $I_{\mathrm{c}}$, ranging from 0.8 to $20 \mu \mathrm{E} \mathrm{m} \mathrm{m}^{-2} \mathrm{~s}^{-1}$, compared with the observed depth of the deep fluorescence maximum for unperturbed stations in August 1999. The best agreement between observed and predicted depths stems from $I_{\mathrm{c}}$ of 10 to $20 \mu \mathrm{E} \mathrm{m} \mathrm{m}^{-2} \mathrm{~s}^{-1}$. Values of surface irradiance, $I_{0}$, in Eq. (3) were taken from $5 \mathrm{~d}$ averages from the ship's pyrrheliometer, converted to $24 \mathrm{~h}$ mean PAR; $m$ was 0.60 ; PAR diffuse attenuation, $k$, was calculated from surface-layer fluorescence, using Eq. (4). Lines fitted to each set of compensation irradiances are third-order polynomials.

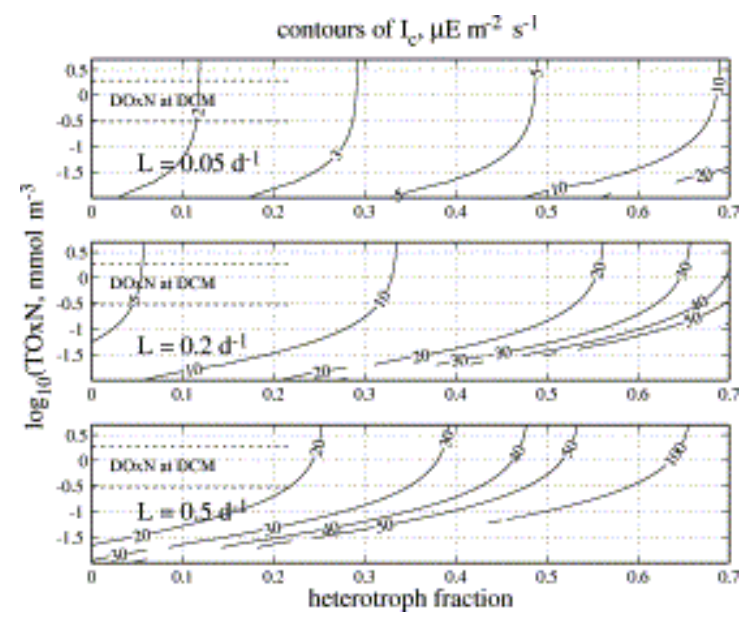

Fig. 8. Contour plots for the microplankton compensation irradiance $I_{\mathrm{c}}$ at three values of "external" loss rate, $L$, the heterotroph fraction, $\eta$, and the external concentration, $S$, of $\mathrm{TO}_{x} \mathrm{~N}$. The plots were generated using the equation set (9)-(12) with the standard parameter values in Table 2. 


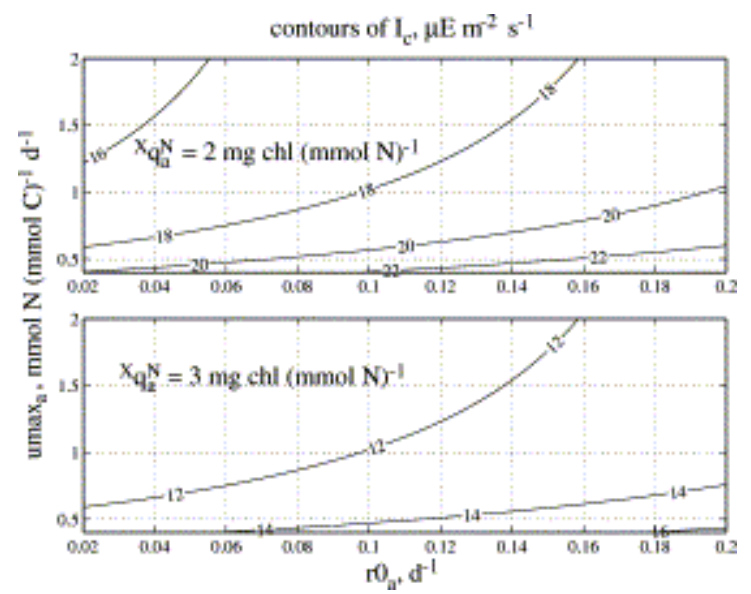

Fig. 9. Sensitivity of the predictions of the compensation irradiance $I_{\mathrm{c}}$ to values of the autotroph parameters for: maximum nitrate uptake $\left(\right.$ at $\left.20^{\circ} \mathrm{C}\right), u_{\text {mik a a }}$; basal respiration, $r_{0 \mathrm{a}}$; and the chlorophyll yield from nitrogen, ${ }^{X} q^{N}$ a. The fixed values of the variables of Fig. 8, were: $L=0.15 \mathrm{~d}^{-1} ; S=1.0 \mathrm{mmol} \mathrm{m}^{-3} ; \eta=0.45$.

Table 1 Estimates of photosynthetic efficiency for phytoplankton from the DCM at unperturbed stations

\begin{tabular}{|l|l|l|l|l|}
\hline Month and year & Station & Depth & $\begin{array}{l}\alpha \mathrm{m} \\
\left(\mathrm{mg} \mathrm{C}_{\left(\mathrm{mg} \mathrm{chl}^{-1}\right)^{-1}}^{-1}\right. \\
\left.\left(\mu \mathrm{Em}^{-1}\right)^{-1}\right)\end{array}$ & $\begin{array}{l}\text { Standard error of } \\
\text { parameter estimate }\end{array}$ \\
\hline August 1993 & 1 & 80 & 0.023 & \\
\hline August 1993 & 18 & 80 & 0.020 & \\
\hline August 1993 & 132 & 60 & 0.023 & 0.002 \\
\hline August 1993 & 144 & 75 & 0.0032 & 0.002 \\
\hline August 1999 & 1 & 100 & 0.025 & 0.001 \\
\hline August 1999 & 5 & 75 & 0.016 & \\
\hline August 1999 & 18 & 50 & 0.025 & \\
\hline
\end{tabular}

1993 data from Basterretxea and Arístegui (2000).

Table 2 Definitions of symbols used in the models including values (from Tett, 1998, unless otherwise stated) where appropriate

\begin{tabular}{|l|l|l|l|}
\hline Symbol & Definition/description & Value & Units \\
\hline
\end{tabular}




\begin{tabular}{|c|c|c|c|}
\hline \multicolumn{4}{|c|}{ State variables } \\
\hline$B$ & $\begin{array}{l}\text { Microplankton biomass measured as organic } \\
\text { carbon }\end{array}$ & & $\mathrm{mmol} \mathrm{Cm}^{-3}$ \\
\hline$Q$ & $\begin{array}{l}\text { Ratio of nitrogen to organic carbon in } \\
\text { microplankton }\end{array}$ & & $\begin{array}{ll}\mathrm{mmol} & \mathrm{N} \\
(\mathrm{mmol} \mathrm{C})^{-1} & \end{array}$ \\
\hline$S$ & $\begin{array}{l}\text { Concentration of nitrate+nitrite }\left(\mathrm{TO}_{\mathrm{x}} \mathrm{N}\right) \text { in sea } \\
\text { water }\end{array}$ & & $\mathrm{mmol} \mathrm{Nm}^{-3}$ \\
\hline$X$ & $\begin{array}{l}\text { Chlorophyll concentration by standard field } \\
\text { method (i.e., chlorophyll a plus related } \\
\text { pigments, but not pheopigments) }\end{array}$ & & mg chlm ${ }^{-3}$ \\
\hline \multicolumn{4}{|c|}{ Rate variables } \\
\hline$G$ & $\begin{array}{l}\text { Mesozooplankton grazing pressure: relative rate } \\
\text { of } \\
\text { removal of microplankton biomass }\end{array}$ & & $d-1$ \\
\hline$r$ & $\begin{array}{l}\text { Microplankton (relative) respiration rate: } r=r_{0} \\
+b \mu\end{array}$ & & $d^{-1}$ \\
\hline$u$ & $\begin{array}{l}\text { Microplankton nitrate+nitrite uptake rate relative } \\
\text { to biomass }\end{array}$ & & $\begin{array}{l}\mathrm{mmol} \\
(\mathrm{mmol} \mathrm{C})^{-1} \mathrm{~d}^{-1}\end{array}$ \\
\hline$\mu$ & $\begin{array}{l}\text { Microplankton (relative) growth rate : } \mu= \\
\min \{\mu(I), \mu(Q)\}\end{array}$ & & $d^{-1}$ \\
\hline$\varphi$ & Vertical flux of microplankton biomass & & $\mathrm{mmol} \mathrm{m} \mathrm{d}^{-1}$ \\
\hline \multicolumn{4}{|c|}{ Microplankton bulk parameters } \\
\hline$w_{\mathrm{B}}$ & Sinking rate (see text) & 0 & $\mathrm{md}^{-1}$ \\
\hline$\chi$ & $\begin{array}{l}\text { Ratio of chlorophyll to microplankton carbon } \\
\text { biomass }\end{array}$ & & $\begin{array}{l}\mathrm{mg} \quad \mathrm{chl} \\
(\mathrm{mmol} \mathrm{C})^{-1}\end{array}$ \\
\hline y & $\begin{array}{l}\text { Ratio of chlorophyll to microplankton carbon } \\
\text { biomass } \mathrm{y}=B_{\mathrm{h}} /\left(B_{\mathrm{a}}+B_{\mathrm{h}}\right)\end{array}$ & $0-1$ & \\
\hline
\end{tabular}




\begin{tabular}{|c|c|c|c|}
\hline \multicolumn{4}{|c|}{ Autotroph (phytoplankton) photosynthetic parameters } \\
\hline$\alpha_{\mathrm{m}}$ & $\begin{array}{l}\text { (maximum) photosynthetic "efficiency"; in } \\
\text { theory, } \alpha_{\mathrm{m}}=\text { c.e. } \Phi, \text { where } c \text { converts units }\end{array}$ & $\begin{array}{l}0.044- \\
0.162\end{array}$ & $\begin{array}{l}\text { mmol C }(\mathrm{mg} \\
\mathrm{chl})^{-1} \mathrm{~d}^{-1}\left(\mu \mathrm{Em}^{-}\right. \\
\left.2_{\mathrm{s}}-1\right)^{-1}\end{array}$ \\
\hline$\chi_{\mathrm{a}}$ & $\begin{array}{l}\text { Phytoplankton chlorophyll content in } \\
\text { "classical" model (Tett and Droop, 1988) }\end{array}$ & $0.4^{\mathrm{a}}$ & $\begin{array}{l}\mathrm{mg} \\
(\mathrm{mmol} \mathrm{C})^{-1}\end{array}$ \\
\hline$\varepsilon$ & $\begin{array}{l}\text { Scalar PAR absorption cross-section for oceanic } \\
\text { phytoplankters (Tett, 1990a) }\end{array}$ & 0.04 & $\mathrm{~m}^{2}(\mathrm{mg} \mathrm{chl})^{-1}$ \\
\hline$\Phi$ & Quantum yield of photosynthesis & 40 & Nmol C $\mu^{-1}$ \\
\hline \multicolumn{4}{|c|}{ Autotroph (phytoplankton) other parameters } \\
\hline$b_{\mathrm{a}}$ & Respiration slope & 0.5 & (ratio) \\
\hline$k_{\mathrm{S}}$ & Half-saturation concentration for nitrate uptake & 0.32 & $\mathrm{mmol} \mathrm{N} \mathrm{m}^{-3}$ \\
\hline$Q_{\max \text { a }}$ & Maximum nitrogen quota & 0.20 & $\begin{array}{ll}\mathrm{mmol} & \mathrm{N} \\
(\mathrm{mmol} \mathrm{C})^{-1} & \end{array}$ \\
\hline$Q_{\min \text { a }}$ & Minimum nitrogen quota & 0.05 & $\begin{array}{ll}\mathrm{mmol} & \mathrm{N} \\
(\mathrm{mmol} \mathrm{C})^{-1} & \end{array}$ \\
\hline $\mathrm{x}_{\mathrm{q}_{\mathrm{a}}}{ }^{\mathrm{N}}$ & Yield of chlorophyll from nitrogen & 3.0 & $\begin{array}{l}\mathrm{mg} \text { chl }(\mathrm{mmol} \\
\mathrm{N})^{-1}\end{array}$ \\
\hline $\mathrm{r}_{0 \mathrm{a}}$ & Basal respiration rate & $0.05^{\mathrm{b}}$ & $d^{-1}$ \\
\hline${ }^{\mathrm{NO}} \mu_{\operatorname{maxa}}$ & Maximum nitrate+nitrite uptake rate & $1.67^{\mathrm{a}}$ & $\begin{array}{l}\mathrm{mmol} \\
(\mathrm{mmol} \mathrm{C})^{-1} \mathrm{~d}^{-1}\end{array}$ \\
\hline \multicolumn{4}{|c|}{ Microheterotroph parameters } \\
\hline$b_{\mathrm{h}}$ & Heterotroph respiration slope & 1.5 (std.) & (ratio) \\
\hline$q_{\mathrm{h}}$ & Heterotroph (constant) nitrogen:carbon ratio & $0.18(\mathrm{std})$ & $\begin{array}{ll}\mathrm{mmol} & \mathrm{N} \\
(\mathrm{mmol} \mathrm{C})^{-1} & \end{array}$ \\
\hline$r_{0 \mathrm{~h}}$ & Heterotroph basal respiration rate & $0.07(\mathrm{std})$ & $d-1$ \\
\hline \multicolumn{4}{|c|}{ Optical terms } \\
\hline
\end{tabular}




\begin{tabular}{|c|c|c|c|}
\hline$I(\mathrm{z})$ & Downwelling diffuse PAR at depth $\mathrm{z}$ & & $\mu \mathrm{Em}^{-2} \mathrm{~s}^{-1}$ \\
\hline$I_{0}$ & Observed $24 \mathrm{~h}$ mean PAR at sea surface & c. 500 & $\mu^{\mathrm{Em}^{-2} \mathrm{~s}^{-1}}$ \\
\hline$I_{\mathrm{c}}$ & Model-predicted compensation PAR & $0.8-20$ & $\mu^{\mathrm{Em}^{-2} \mathrm{~s}^{-1}}$ \\
\hline$k$ & $\begin{array}{l}\text { Observed or locally estimated diffuse } \\
\text { attentuation coefficient for (most penetrating) } \\
\text { downwelling PAR }\end{array}$ & $\begin{array}{l}0.04- \\
0.11\end{array}$ & $\mathrm{~m}^{-1}$ \\
\hline$m$ & $\begin{array}{l}\text { Locally estimated factor correcting for surface } \\
\text { reflection, hyperexponential near-surface decay, } \\
\text { and differences between submarine radiometer } \\
\text { and shop's pyrrheliometer }\end{array}$ & 0.6 & $\mathrm{~m}^{-1}$ \\
\hline \multicolumn{4}{|c|}{ Other terms } \\
\hline$K_{\mathrm{z}}$ & $\begin{array}{l}\text { Vertical eddy diffusion coefficient in DCM } \\
\text { (Wild, 1995) }\end{array}$ & 1.1 & $m^{2} d^{-1}$ \\
\hline$l_{\mathrm{V}}$ & $\begin{array}{l}\text { Observed vertical length-scale of DCM (depth } \\
\text { interval over which fluorescence was at least } \\
\text { half the maximum value) }\end{array}$ & $10-50$ & $\mathrm{~m}$ \\
\hline$l$ & $\begin{array}{l}\text { Total relative loss rate of microplankton, due to } \\
\text { vertical mixing, sinking, and mesozooplankton } \\
\text { grazing }\end{array}$ & Up to 0.2 & $\mathrm{~d}^{-1}$ \\
\hline
\end{tabular}

${ }^{\text {a }}$ At $20^{\circ} \mathrm{C}$; varies with temperature according to function of Eppley (1972) but with $Q_{10}$ $=2: 0$ : The standard value, in the microplankton model (Tett, 1998), for the maximum uptake rate of nitrate, ${ }^{\mathrm{NO}} u_{\max }$ a, is $0.5 \mathrm{mmol} \mathrm{N}(\mathrm{mmol} \mathrm{C})^{-1} \mathrm{~d}^{-1}$. This was adjusted on the grounds that uptake is a property of the surface of cells. The surface area of two cells, related to their volumes, is in the proportion $d_{2}: d_{1} . d_{1}$ was taken as $3 \mu \mathrm{m}$ in contrast to the standard size $\left(d_{2}\right)$ of $10 \mu \mathrm{m}$.

${ }^{\mathrm{b}}$ Note (presumed) absence of temperature and size effect.

Table 3

Two scenarios for a typical compensation irradiance

\begin{tabular}{|l|l|l|l|l|l|l|l|}
\hline Scenario & & A & & & & B & \\
\hline Heterotroph & & 0.6 & & & & 0.0 & \\
fraction, y & & 0 & & & & 0 & \\
\hline Component & Rate & & Equivalen & & Equivalen & & Rate \\
\hline
\end{tabular}




\begin{tabular}{|c|c|c|c|c|c|}
\hline $\begin{array}{l}\text { (normalised to } \\
\text { microplankton } \\
\text { carbon biomass) }\end{array}$ & $\left(d^{-1}\right)$ & $\begin{array}{ll}\mathrm{t} \quad 24 & \mathrm{~h} \\
\text { mean } & \\
\text { PAR } & \\
\left(\mu \mathrm{Em}^{-2} \mathrm{~s}^{-}\right. \\
\left.{ }^{1}\right)\end{array}$ & & $\begin{array}{ll}\mathrm{t} \quad 24 & \mathrm{~h} \\
\text { mean } & \\
\text { PAR } & \\
\left(\mu \mathrm{Em}^{-2} \mathrm{~s}^{-}\right. \\
\left.{ }^{1}\right)\end{array}$ & $\left(d^{-1}\right)$ \\
\hline $\begin{array}{l}\text { Gross } \\
\text { photosynthesis }\end{array}$ & $\begin{array}{l}0.31 \\
0\end{array}$ & 10.0 & $\begin{array}{l}\text { Ic, } \\
\text { compensatio } \\
\mathrm{n} \text { irradiance }\end{array}$ & 10.0 & $\begin{array}{l}0.76 \\
6\end{array}$ \\
\hline $\begin{array}{l}\text { Respiration of } \\
\text { autotrophs }\end{array}$ & $\begin{array}{l}0.01 \\
7 \\
\end{array}$ & 3.8 & $\begin{array}{ll}\begin{array}{l}\text { Photon flux } \\
\text { density }\end{array} \\
\end{array}$ & 3.8 & $\begin{array}{l}0.29 \\
0 \\
\end{array}$ \\
\hline $\begin{array}{l}\text { Respiration of } \\
\text { microheterotroph } \\
\mathrm{s}\end{array}$ & $\begin{array}{l}0.11 \\
3\end{array}$ & 3.6 & $\begin{array}{l}\text { Required to } \\
\text { balance }\end{array}$ & 0.0 & $\begin{array}{l}0.00 \\
0\end{array}$ \\
\hline Mixing loss & $\begin{array}{l}0.02 \\
0 \\
\end{array}$ & 0.6 & Each loss & 1.0 & $\begin{array}{l}0.08 \\
0 \\
\end{array}$ \\
\hline $\begin{array}{l}\text { Mesozooplankton } \\
\text { grazing loss }\end{array}$ & $\begin{array}{l}0.06 \\
0 \\
\end{array}$ & 2.0 & & 5.2 & $\begin{array}{l}0.39 \\
6 \\
\end{array}$ \\
\hline Balance & $\begin{array}{l}0.00 \\
0 \\
\end{array}$ & 0.0 & & 0.0 & $\begin{array}{l}0.00 \\
0\end{array}$ \\
\hline
\end{tabular}

In each case the compensation irradiance was set to a typical Canaries waters value of $10 \mu \mathrm{Em}^{-2} \mathrm{~s}^{-1}$ The rates were obtained by solving the model of Eqs. (9)-(12) for $S=1.0$ mmol $\mathrm{DO}_{\mathrm{x}} \mathrm{Nm}^{-3}$ and for the external losses $L$ equal to the total of mixing and mesozooplankton grazing. Scenario A emphasises the activity of the microbial loop, with $y=0.6$. Scenario $B$ calculates the mesozooplankton grazing loss that would be required if $\mathrm{y}=0.0$. The range of mixing losses is that calculated for the Canaries waters observations in 1999 , assuming $K_{\mathrm{z}}=1.1 \mathrm{~m}^{2} \mathrm{~d}^{-1}$ in the thermocline 